Peacekeeping's Poor Cousin:

Canada and the Challenge of Post-Conflict Policing

Timothy Donais

YCISS Working Paper Number 29

August 2004 


\title{
Peacekeeping's Poor Cousin: Canada and the Challenge of Post-Conflict Policing
}

\author{
Timothy Donais \\ Canadian Consortium on Human Security (CCHS) \\ Post-Doctoral Fellow ${ }^{1}$
}

YCISS Working Paper Number 29

August 2004

The YCISS Working Paper Series is designed to stimulate feedback from other experts in the field. The series explores topical themes that reflect work being undertaken at the Centre.

\footnotetext{
${ }^{1}$ Research for this paper was made possible through the financial support of both the Canadian Consortium on Human Security (CCHS) and the Human Security Program of Canada's Department of Foreign Affairs and International Trade (DFAIT). The views presented here are those of the author and do not necessarily represent those of the CCHS or its affiliated institutions. The author also gratefully acknowledges the contributions to this paper of participants at the workshop "Canada and the Challenge of Post-Conflict Policing," organized by York University's Centre for International and Security Studies in conjunction with the Nathanson Centre for the Study of Organized Crime and Corruption, held at the Canadian Police College in Ottawa on 30 April 2004. Particular thanks are due to Doug Coates, Paul LaRoseEdwards, and Katie Kerr.
} 
Donais $\uparrow$ Canada and the Challenge of Post-Conflict Policing / 1

For much of the past decade, Canada has been deeply engaged in the effort to remake Haiti's police forces in the image of a modern, democratic police service. As part of successive United Nations police support missions, upwards of 700 Canadian police officers served in Haiti during this period, mentoring and training their local counterparts and carrying out some law enforcement responsibilities. Haiti's recent descent back into chaos and lawlessness following the flight of President Jean-Bertrand Aristide, however, has left this process, as well as the broader international effort to stabilize the hemisphere's most volatile and strife-ridden state, in ruins. Once again, the outside world - while hardly innocent in Haiti's most recent bout of instability - finds itself struggling to restore order, security, and some measure of democracy to Haiti. And once again, Canada is part of a longer-term international effort to transform Haiti's police, which had become increasingly corrupt, politicized, and thuggish, into a force for peace, order, and stability. While seemingly a Sisyphean task, the stakes surrounding police reform in Haiti are particularly high. With the disbanding of the Haitian military in 1994, the Haitian National Police now stands as the country's key security sector institution, and the most visible means through which the Haitian state has attempted to exercise its legitimate authority. For the international community, failing to get it right this time may simply set the stage for Haiti's next round of turmoil.

Haiti's recurring nightmare dramatically illustrates the importance of addressing questions of security sector reform in weak, unstable, or post-conflict states, and underlines the direct links between an ineffective security sector and human insecurity. A relatively recent addition to the international relations lexicon, the notion of security sector reform refers to efforts to strengthen the full range of tools at the disposal of states - from armies and police to courts, penal institutions, and intelligence services with which to exercise their monopoly on the legitimate use of force. At its core, security sector reform is based on the principle that a state's security institutions should be democratically controlled, anchored in the rule of law, and most importantly, sources of security rather than insecurity for citizens.

This paper examines Canadian experiences, policies, and practices with regard to police reform a key element of the security sector reform agenda - in post-conflict or failed states. While an entire mythology has developed around Canada's role as originator and long-standing champion of peacekeeping in its military guise, less attention has been paid to policing as the second core pillar of security in transitions from conflict to peace. This is gradually changing, as the limitations of military peacekeepers as agents of peacebuilding become more evident, and as it is increasingly recognized that building sustainable peace in the absence of minimal levels of public security is next to impossible.

In many ways, post-conflict police assistance - including the provision of international civilian police for monitoring or law enforcement roles as well as longer-term training and institutional development assistance - is an issue tailor-made for Canadian foreign policy, combining national commitments to human security, to peacebuilding, and to the export of core Canadian values such as peace, order, and good government. However, while Canada's contributions in this area to date are far from negligible, neither has it been an international leader. The paper will assess Canada's contributions, and the possibilities for greater Canadian involvement, in this area. It will consider both domestic and 
international obstacles to a greater Canadian role - such as chronic personnel shortages, interdepartmental politics, and the hodgepodge of inadequately coordinated institutional actors already active in the field - and examine ways in which some of these challenges might be overcome.

\section{Policing Post-Conflict Zones: The Evolving International Context}

While it is now widely recognized that most contemporary conflicts occur within states rather than between them, the international community is only slowly coming to terms with this new reality in terms of its conflict management toolkit. In the early 1990s, Bosnia in particular demonstrated the inadequacy of conventional peacekeeping in the face of unconventional ethnic conflict, in which there were few clearly-demarcated front lines, little distinction between combatants and civilians, and precious little peace to keep. At the same time, it has become evident that post-conflict peacebuilding in divided societies is less about separating opposing armed forces and more about a sustained process of statebuilding. If state-building equals peacebuilding in the contemporary era, then the most that outside military forces can contribute to this effort is to create a reasonably stable environment in which the state-building process - which involves not only establishing sustainable institutions but also generating domestic confidence in them - can occur.

Given the violent context from which post-conflict states struggle to emerge, it seems uncontroversial to suggest that among the most important institutions to be re-constructed as part of the peacebuilding process are those related to security. Clearly, if the citizens of war-torn states cannot rely on state institutions to provide for their security, they will have little incentive to either put down their arms or abandon 'their' side of the armed struggle. As Annika Hansen has suggested, "security is the key to a "new social contract" between the population and its government or society in which the population is willing to surrender the responsibility for its physical safety into government hands." It is here, then, that security sector reform and peacebuilding intersect, with success in the former realm a key contributing factor in the success of the overall peace process.

Particularly in cases of intra-state conflict, recent experience underlines the fact that those internal security sector institutions underpinning the rule of law are just as important as military institutions in the transition from war to peace. A key task of international peacekeeping efforts has been to isolate, contain, and remove domestic military forces from the political process, and ultimately redirect their energies towards external rather than internal security tasks. Sustainable peace, however, requires an equally concerted effort to establish internal security and the rule of law by strengthening, professionalizing, and de-politicizing police, courts, and penal institutions.

In fragile and highly-politicized post-conflict environments, none of these processes can be expected to unfold quickly or easily. Within the security sector, therefore, peacebuilding processes can

\footnotetext{
${ }^{1}$ Annika Hansen, "International Security Assistance to War-torn Societies," in Michael Pugh, ed., Regeneration of War-Torn Societies (New York: St. Martin's Press 2000), 35.
} 
usually be understood as unfolding in two, often overlapping stages: the direct international provision of security in the interim period before domestic institutions are up to taking on these tasks themselves, and the necessarily longer-term processes of building capacity within domestic security institutions.

With a few prominent exceptions, however, the international community has been reluctant to impose both military and public security in post-conflict environments, despite recognizing the importance of each. This reluctance has allowed significant post-conflict security gaps to emerge, with predictably deleterious consequences for fragile peace processes. Typically, security responsibilities in post-conflict environments are divided among military peacekeepers, local police, and international civilian police. Just as typically, the former have been unwilling and unprepared to take on mundane public security tasks, the latter have been under-powered and under-resourced, while local police establishments are often as much a part of the problem as part of the solution. More recently, and more troublingly, post-conflict operations in both Iraq and Afghanistan have unfolded in the absence of an active international civilian police presence. This situation has left huge gaps in security provision between international military forces, focused on force protection and terrorism interdiction, and local police forces, which are hopelessly under-resourced and overwhelmed by the chaotic and lawless conditions of the after-war period.

The dangers of allowing post-conflict security gaps to persist in post-conflict environments are many. In this relatively lawless interregnum between war and peace, petty thieves, organized criminals and remnants of ousted regimes may begin to regroup and assert themselves, ethnic or factional tensions may boil over into open conflict, forms of retributive or vigilante justice may emerge, and there are real risks of local communities turning against a peace process that appears incapable of delivering security. At the same time, international actors, in the face of persistent insecurity, may begin to lose both credibility and resolve as time lines for achieving sustainable peace grow ever longer. In the worst-case scenario, any viable peace process is swamped by the combination of an increasingly criminalized political economy, an untenable public security situation, and the re-emergence of ethnic or factional conflict. To greater or lesser degrees, all of these malign consequences have been evident in peacebuilding processes in places like Bosnia, Kosovo, Iraq, Afghanistan, and Haiti.

To a large extent, militarized peacekeeping or peace-enforcement forces are incapable of adequately addressing many of the public security challenges faced by post-conflict societies. As Charles Call and William Stanley have argued, "most militaries are not appropriate for public security tasks, since their training, equipment, and doctrine emphasize use of overwhelming force rather than the controlled application of force necessary for police work." ${ }^{2}$ At the same time, soldiers are also reluctant

\footnotetext{
${ }^{2}$ Charles T. Call and William Stanley, "Protecting the People: Public Security Choices After Civil Wars," Global Governance 7 (2001), 157; see also Rachel Bronson, "When Soldiers Become Cops," Foreign Affairs 81:6 (November-December 2002).
} 
agents of law enforcement, and most militaries tend to view public security work as thankless, dull, and a misuse of valuable war-fighting capacity.

International civilian police missions, or CIVPOL in UN terminology, emerged at least partly in response to the unmet security needs of post-conflict environments. With the exceptions of Kosovo and East Timor, however, where international police were given executive law enforcement authority, international police missions have typically been provided with weak mandates and inadequate resources and asked to radically transform domestic security environments. At the same time, the reputation of international civilian police has not been helped by the UN's inability to effectively manage international police officers from dozens of member states representing an equal number of different policing cultures, or to ensure that individual police monitors meet minimal requirements in terms of skills and professionalism. In terms of stature, organization, and resources then, the civilian policing component of the international post-conflict security architecture is unquestionably the poor cousin of its more celebrated military counterpart.

If anything, the difficult realities of contemporary post-conflict environments have made this gap between international capacities in military security provision and public security provision that much more apparent. Notwithstanding the current turmoil in Iraq, militarized peacekeeping and peaceenforcement missions have become relatively efficient at establishing a base level of military security in post-conflict environments, especially when backed by the overwhelming military power of the United States. The development of international capacities in the provision of post-conflict public security over the past decade, on the other hand, has been somewhat haphazard and uneven. Consequently, finding ways to simultaneously stabilize the public security situation in strife-torn states, while at the same time building up domestic law and order capacities, remains one of the international community's key peacebuilding challenges.

\section{The Canadian Contribution: Past, Present, and Future}

The Canadian police experience with modern peacekeeping began in 1989, when some 100 officers were deployed to Namibia to help oversee transitional elections. Canadian police officers have subsequently been involved in many of the most prominent peace support missions of the past 15 years. Yet while the role of international police as an integral component of peacekeeping and peacebuilding efforts has been growing, Canadian commitments and capacities in this area have evolved only marginally. While Canadian police officers are, and continue to be, widely respected abroad for their professionalism, Canada's mechanisms for identifying, preparing, and deploying police officers for post-conflict work continue to be largely ad hoc and provisional. At the same time, over the course of the past half-decade Canada has rarely managed to have more than 100 police officers deployed in peace operations at any one time, despite widespread recognition among policy-makers that Canada could, and probably should, be doing more. While Canadian contributions are not markedly out of line with the contributions of other Western states (even if well below the contributions of developing states such as Jordan), Canada is 
far from an international leader in contributing to multinational police support efforts. Presently, according to the UN's most recent monthly statistics, Canada is contributing 45 civilian police to UN peace operations, fewer than countries such as Fiji, Bulgaria, and Ghana. ${ }^{3}$

Since 1997, the deployment of Canadian police personnel in international peace support operations has been governed by the Canadian Police Arrangement (CPA), a funding and administrative mechanism involving four major government actors: the Department of Foreign Affairs and International Trade (now Foreign Affairs Canada), the Canadian International Development Agency (CIDA), the Royal Canadian Mounted Police (RCMP), and the Department of the Solicitor General. Foreign Affairs provides the policy lead, CIDA provides the funding - some $\$ 19$ million over three years under the current agreement - while the RCMP provides the bulk of personnel. In recent years, however, the RCMP has developed partnerships with local and regional police forces across the country, which now provide close to half of all officers for international missions. Currently, the CPA provides sufficient funding to enable some 42 Canadian police officers to be deployed internationally each year, although in cases of larger deployments, CPA funding is topped up from other government sources. The CPA does not provide for a dedicated pool of officers on standby for international missions; rather it facilitates the selection and deployment of officers on a case-by-case basis, primarily in response to requests from multilateral organizations such as the UN.

While many of those familiar with the CPA insist that it has worked reasonably well over the past seven years, there is also a widespread consensus that it is no longer adequate. ${ }^{4}$ Indeed, the CPA was initially meant to be a temporary arrangement, put in place until a more permanent arrangement could be developed and implemented..$^{5}$ Now in its eighth year, however, the CPA appears increasingly to be a permanent fixture of Canada's foreign policy landscape.

Lying as it does at the intersection of foreign policy, international development, and policing, the issue of Canadian support to post-conflict policing has been marked by divergent policy priorities among the relevant participating departments. While formally managed by an interdepartmental committee representing Canada's development, foreign affairs, and policing communities, the Canadian Police Arrangement has never been firmly anchored in a coherent national strategic vision around Canada's role in post-conflict public security. For its part, Foreign Affairs has led on the policy side, and has a clear interest in an effective Canadian contribution to post-conflict policing as a means of enhancing Canada's

\footnotetext{
3 “Monthly Summary of Contributions to UN Peacekeeping Operations," United Nations, 31 July 2004; Available from http://www.un.org/Depts/dpko/dpko/contributors/CountriesSummaryJuly2004.pdf (accessed August 2004); to be fair, it should be noted that Canada is currently contributing some 20 police trainers to train Iraqi police recruits in Jordan, and has recently committed an additional 100 police to the UN's Haiti mission.

${ }^{4}$ These general conclusions, as well as others in this paper, are drawn from the "Canada and the Challenge of PostConflict Policing" workshop (see footnote 1 above).

${ }^{5}$ Doug Coates, “Canadian Police as Peacekeepers,” (Unpublished manuscript, April 2002), 28-30.
} 
stature abroad and advancing its international policy goals, but lacks the financial clout to impose a clear vision and direction. Within CIDA, despite a growing recognition that police reform is a legitimate focus for development assistance, police assistance issues have never been effectively integrated within the agency's broader development programs or strategies. ${ }^{6}$

Limited resources and conflicting mandates have also generated considerable ambivalence towards the issue of international and post-conflict police assistance within the RCMP. On the one hand, there is an awareness that Canada not only has a responsibility to contribute, as part of its broader international commitments, to post-conflict stabilization efforts through police assistance, but that Canada also benefits from such assistance. Not only does it help prevent instability from entering Canada in the form of refugee flows or cross-border crime, but participation in international policing missions gives Canadian police personnel valuable experience. On the other hand, the terms of the CPA often force a trade-off between domestic and international policing. Since the arrangement does not allow the RCMP to hire additional policing resources, every police officer sent on an international mission is one less police officer available for active duty at home. This situation is hardly unique to Canada, and is one of the key distinctions between military peacekeeping forces, who are essentially on standby when stationed in their home countries, and "policekeepers,"7 who typically have ongoing domestic law enforcement responsibilities. In Canada, this reality has tempered the enthusiasm of senior RCMP officials for international police work, since they tend to view such missions as at best a distraction, and at worst an obstacle to the force's ability to perform its core tasks at home.

The absence of a dedicated Canadian standby force of police personnel available for international duty has had a number of implications for the practice of deploying Canadian police officers abroad. While Canada has committed itself to supplying UN police support missions with up to 50 officers on short notice, each request from the UN requires a relatively laborious process of identifying potential candidates who are qualified, willing, and in a position to be released by their superior officers. This system, in addition to being relatively inefficient, also has implications in terms of training for international service. Since officers are not pre-selected, and since Canada aims to provide personnel within eight weeks of an official request, the time frame between selection and deployment provides little opportunity for training. And while Canadian police personnel are widely considered to be well-trained in modern policing methods, even the best-trained officers benefit from additional training aimed at preparing them for the rigours of international police work in unstable postconflict societies. Such supplementary training could include courses on international humanitarian law, on dealing with refugee or displaced populations or with questions of disarmament or demobilization,

\footnotetext{
${ }^{6}$ Author interview with Susan Brown, Pearson Peacekeeping Centre, Ottawa, 14 January 2004.

${ }^{7}$ The term "policekeeper" is closely associated with the recent work of Graham Day; see Graham Day and Christopher Freeman, "Policekeeping is the Key: Rebuilding the Internal Security Architecture of Postwar Iraq," International Affairs 79:2 (2003).
} 
and on the political dynamics of the specific country and conflict to which they are being deployed. ${ }^{8}$ Issues of training and advance preparation are even more pressing given the relatively short rotations between six to twelve months - typical of international police missions. All too often, by the time an individual police monitor fully understands the local environment and is able to operate effectively within it, he or she is being rotated back home again. This revolving door approach to post-conflict policing has eroded both the credibility and the effectiveness of UN police assistance missions.

At the same time, much as the Canadian Police Arrangement has suffered somewhat from being owned by several departments and championed by none, there has been little effort to integrate postconflict policing issues with other elements of the security sector reform agenda, notably corrections or judicial reform. This issue is crucial, since perhaps the clearest lesson from international reform efforts in the rule of law sector is that an effective police force means little if the local judiciary is corrupt or the penal system dysfunctional. In other words, there is a growing recognition that restoring the rule of law in post-conflict states must be a single, integrated process.

At the moment, however, Canada's capacity to deploy justice or penal reform experts into international missions is even less developed than its ability to deploy police officers. While Canadian personnel in these areas have served in international missions, Canada's approach is far from systematic, and there has been little effort made to focus Canadian deployments in the areas of policing, justice, and corrections into a coherent and integrated security sector reform strategy. ${ }^{9}$ Again, Canada is far from the only country grappling with such issues, and both the United Kingdom and the United States may offer some useful models for Canada as it contemplates future approaches in this area. In 2001, for example, the UK initiated a Global Conflict Prevention Pool, an exercise in 'joined-up government' aimed at pooling resources and strategies from the UK Ministry of Defence, the Foreign and Commonwealth Office, and the Department for International Development into a coherent national strategy for conflict reduction. The pool has enabled the participating departments to develop and implement joint strategies geographically, as in Afghanistan or the Balkans, or thematically, as in the area of small arms and light weapons. ${ }^{10}$ The United States has also acknowledged the inefficiencies of decentralized approaches to security sector reform and post-conflict peacebuilding, and is working towards the establishment of an

\footnotetext{
${ }^{8}$ Currently, for example, Canadian officers being deployed on international policing missions receive a two-hour briefing on international humanitarian law; author interview with Paul LaRose-Edwards, CANADEM, Ottawa, 15 January 2004.

${ }^{9}$ Comments made by DFAIT's Wendy Gilmour at the workshop "Canada and the Challenge of Post-Conflict Policing," Ottawa, 30 April 2004.

${ }^{10}$ See Louise Bell, The Global Conflict Prevention Pool: A joint UK government approach to reducing conflict (London: UK Foreign and Commonwealth Office, August 2003); Available from http://www.dfid.gov.uk/Pubs/files/global_conflict_prevention_pool.pdf(accessed May 2004).
} 
Office of Post-Conflict Stabilization in order to lend clearer focus and greater coherence to US peacebuilding efforts. ${ }^{11}$

Canada has neither the international clout nor the financial resources of its more powerful allies, and thus might ultimately have to choose between either broadening or deepening its commitments to international security sector reform. Yet whether Canada chooses to develop coherent security sector approaches to be applied in long-term engagements with countries such as Haiti, or strives to become an international leader in the area of post-conflict police assistance, either would be a significant improvement over the current state of affairs. As it stands now, there is a real danger that Canada's commitment to engaged multilateralism in international peace and security issues is becoming more legend than reality.

\section{The Challenge of Multilateralism}

Of course, given the previously mentioned problems with existing international mechanisms for the provision of post-conflict police assistance, there are legitimate questions to be raised as to whether, and why, Canada would want to funnel significant resources into a system that is highly inefficient, if not wholly dysfunctional. It is also the case that in the case of post-conflict policing, ineffective international mechanisms regularly meet nearly intractable problems within post-conflict environments. Post-conflict police reform - as the Haiti case demonstrates with striking clarity - almost invariably involve painstaking, long-term commitments, multiple and overlapping tasks and responsibilities, and uncertain rewards in terms of concrete, measurable, and sustainable indicators of success. Why, then, should we bother?

With regard to the inherent difficulty and thanklessness of post-conflict policing, the short answer is that simply avoiding the difficult problems will not make them go away. As argued above, the restoration of effective policing is now a crucial element of any peacebuilding process, and failure here comes with a high risk of renewed conflict and instability. And as James Traub has recently written in the context of post-conflict nation-building more generally:

What is almost impossible turns out to be indispensable. It has become obvious since 9/11 that we cannot allow collapsed states, or rogue states, to fester: their failures have become our problem. Nation-building is no longer a subject for debate: we will get it right or pay the price. ${ }^{12}$

Concerning the well-publicized inefficiencies of UN peacekeeping missions, one possible option for Canada could be to direct more of its international policing resources along bilateral channels. Over the

\footnotetext{
${ }^{11}$ Comments made by Dick Mayer, former deputy director of the United States' International Criminal Investigative Training Assistance Program (ICIT AP), at the workshop "Canada and the Challenge of Post-Conflict Policing," Ottawa, 30 April 2004.

12 James Traub, "Nation Building: Making Sense of the Mission,” New York Times Magazine, 11 April $2004,34$.
} 
past several years, in fact, CIDA has funded numerous bilateral assistance projects, among them a capacity-building project for the Afghan National Police and a multi-year project - carried out by the Pearson Peacekeeping Centre - aimed at preparing military and police personnel from Francophone Africa to participate in international peace support operations. While such projects clearly make an important contribution, within post-conflict situations donor-state bilateralism regularly exacerbates problems of international coherence and coordination, problems which can dilute the impact of individual projects. For all its warts, and particularly within the context of immediate post-conflict environments, the UN is often the only institution with the credibility, legitimacy, and ability to take on the complex and long-term challenge of re-engineering domestic security institutions. There is, therefore, is a strong practical case to be made for Canada continuing to work within multilateral policing frameworks, while at the same time pushing for improvements in the realm of policy and practice.

Indeed, given Canada's past experience and its strong policing tradition, there is much that Canada could contribute to a broader, long-term effort to enhance international and UN capacities in the area of post-conflict police assistance. Several key problems within the current UN approach to postconflict policing can be identified, and in each of these Canada could potentially contribute at least partial solutions.

Personnel Training and Preparation: An oft-cited problem with international policing missions is the rather uneven quality of personnel deployed to such missions. Part of the problem is the UN's relatively underdeveloped capacities in the area of pre-deployment and continuing training for its mission staff, which are exacerbated by the failure of countries, like Canada, to provide pre-deployment training of any significance. A second issue, far more sensitive because of its racial overtones, is the question of the training and competence of international police officers from developing nations. A near-universal sentiment among Western police officers with experience in international missions is a sense of frustration with counterparts from developing nations who show up in mission unable to drive, to speak English, or perform basic policing duties in accordance with accepted international standards. ${ }^{13}$ To be fair, the situation has improved over the past decade or so as UN standards have been gradually tightened. However, significant questions still remain, among both Western police officers and the populations of post-conflict states, about the qualifications and credibility of officers from developing countries - especially those with dubious human rights records - as trainers, mentors, and role models.

Regardless of the depths of the North-South divide in policing capacities, much more could be done to prepare police officers from all nations for international missions. Canada, for its part, has a developing capacity in this area, which could feed into a broader international training regime for international police work in post-conflict zones. Organizations such as the Pearson Peacekeeping Centre and CANADEM, an Ottawa-based non-governmental organization which manages the deployment of

\footnotetext{
${ }^{13}$ Author discussions and interviews with well over a dozen North American police officers with international experience, August 2003 - April 2004.
} 
Canadian civilians into international peace operations, are expanding their efforts in the area of international police training, one element of which involves training police officers of other nations for peace support work. Building up a coherent Canadian capacity in this area, and coordinating this capacity with similar efforts in other countries, could form the basis of an integrated training system for international policekeepers.

Strategic Planning and Development: At a recent Ottawa workshop examining Canadian and international responses to the challenges of post-conflict policing, one consistent theme concerned the lack of, and need for, coherent planning and development in international police support missions. Claude Rochon, a retired Canadian police officer with experience in missions all over the globe, noted that missions in which strategic plans had been developed and implemented were very much the exception rather than the rule. ${ }^{14}$ Such planning is crucial, however, both because of the inherent complexity of police reform and because of the chaotic and fluid nature of most post-conflict environments. In Haiti, for example, a relatively comprehensive international effort to build up the Haitian National Police (HNP) ultimately foundered on questions of professionalism and politicization, as senior Haitian police managers not only failed to ensure accountability within the ranks but also failed to resist politicization of the police apparatus as the country's political crisis deepened. ${ }^{15}$ While police reform in Haiti has in many ways been a victim of the country's broader political crisis, the weaknesses within the HNP that the crisis exposed suggest that greater attention needs to be paid to the quality of police leadership, to questions of accountability up and down the police hierarchy, and to the links between police reform and the broader peacebuilding process.

Strategic planning is all the more important given the regular turnover of personnel in international missions; setting goals, standards, policies and procedures that are clear, consistent and transparent is crucial given endemic problems with personnel continuity, particularly within senior management positions. On top of all this, the multidimensional nature of modern police support operations, which are often asked simultaneously to monitor and mentor local counterparts, recruit and train a new generation of officers, weed out bad apples from existing staff rosters, and re-organize entire national policing infrastructures, requires considerable planning to ensure that these various elements work together as a coherent whole. And while the UN's Civilian Policing Division has been upgraded in recent years, its strategic planning capacities remain largely inadequate in the face of such challenges.

While a country like Canada could not realistically be expected to tackle the challenge of mission strategic planning on its own, there are elements of the broader set of issues with which Canada could

\footnotetext{
${ }^{14}$ Comments made by Claude Rochon, Director of CAN POL, at the workshop "Canada and the Challenge of PostConflict Policing," Ottawa, 30 April 2004.

${ }^{15}$ See, for example, "Report of the Secretary General on the Situation in Haiti," Organization of American States, 20 May 2003; Available from: http://www.oas.org/OA Spage/Haiti_situation/CPdoc3750_03E.htm (accessed August 2004).
} 
usefully engage in an effort to move international planning capacities forward. On its own or in collaboration with like-minded states, Canada could usefully explore options for improving UN postconflict policing capacities in areas such as best practices and lessons learned, or in the development and institutionalization of standard rules, policies and procedures for post-conflict policing operations. Given the legal vacuums that often exist in post-conflict environments, there has also been some discussion of the need to develop a generic legal framework that could guide international police missions, particularly in the early stages of a mission. Canada could also explore the feasibility and desirability of developing such a mechanism.

Standby and Rapid Reaction Capability: Since most police officers have ongoing law enforcement responsibilities in their home countries, questions of availability and staffing have dogged UN police support efforts for years. The challenge of finding enough qualified staff for international missions also, of course, has had implications for the quality of international personnel, as it has forced the UN to focus on quantity over quality. And while there is growing talk of the UN moving to leaner, less personnel-intensive missions in the future, with the burden of law enforcement placed squarely on the shoulders of domestic police within post-conflict states, this may ultimately prove to be wishful thinking. In other words, major police missions à la Kosovo, East Timor, or even Bosnia may not be exceptions to the rule, but rather indicative of the range of post-conflict situations that will continue to test international capacities to deliver post-conflict public security. It may, therefore, not be so easy to simply wish away questions of securing adequate personnel for international policing missions.

In recognition of such realities, the European Union has moved to create a standby force of 5,000 police officers available on short notice to respond to crisis situations. As discussed in more detail below, Canada could follow suit by improving its standby capacities through the creation of a standing international police support unit, which could also serve as both model and inspiration for other states. At the same time, through CANPOL, a division of CANADEM that provides retired police officers for international work, Canada already has a standing pool of experienced officers ready and willing to be deployed on short notice. Working with the UN to institutionalize the use of such personnel, and to streamline procedures through which retired officers are incorporated into international missions, could be another means by which the challenge of finding qualified and available policing personnel could be overcome.

Coordination of Multilateral and Bilateral Efforts: Beyond getting the Canadian and UN houses in order on the question of post-conflict policing, there is also the question of enhancing coordination among the broader international community, including the range of bilateral and multilateral actors involved in police reform in particular cases. Across the security and development sectors, the question of international coordination is a difficult one, and levels of coordination are often so poor as to render nonsensical the very notion of an 'international community.' In many cases, the relevant actors recognize that coordination should be improved, but feel powerless to make it happen. In post-conflict policing operations, the lack of overall donor coordination, combined with an absence of strategic 
planning and direction, often leads to inefficient and ineffective allocation of scarce resources. In some cases, local police forces receive computers when they really need pens and paper, or motorcycles when then need flashlights. ${ }^{16}$

While acknowledging that coordination among a multiplicity of agencies in chaotic post-conflict conditions will remain a considerable challenge, there are things that concerned countries such as Canada could do to improve matters. In the policing field, for example, Canada could seek to identify and promote best practices in the area of international donor coordination. One such example comes from Albania, where an international consortium on law enforcement assistance has been relatively successful in coordinating police assistance efforts across a range of relevant actors. In this area as in others, there is no guarantee that Canadian advocacy will be either heard or heeded. What is certain, however, is that effective police reform in post-conflict environments requires international resources and assets to be used as efficiently as possible, and that the failure of contributing states to take this issue seriously will perpetuate a situation in which disoriented and uncoordinated international responses to chaotic postconflict situations will produce unsatisfactory outcomes.

\section{Future Policy Directions}

Canada is current engaged in a foreign policy review, and there is a compelling case to be made for a review of Canadian policies concerning this country's role in post-conflict policing. As things currently stand, four different options present themselves.

Business as usual: While this option requires no new resources, it leaves in place a policy tool that does not deliver much bang for the buck. It also leaves unaddressed the dissatisfactions of each of the main government players with the current system and leaves Canada without a coherent mechanism to deal with broader questions of security sector reform. However, unless each of the departments involved in the international police assistance file begin to make a clear and coherent case that this is an area in which Canada should be playing a stronger role, this option is also the most likely. From a government decision-making perspective, status quo inertia is rendered more likely because post-conflict police assistance does not enjoy the high profile that the deployment of military peacekeepers does. Conversely, however, the deployment of a handful of police officers to work in relative obscurity in Baghdad or Pristina or Freetown allows Canada to claim that it is contributing to post-conflict public security across the globe without a major commitment of money or personnel.

Greater use of retired officers: This option also entails minimal risk or commitment on the part of the Canadian government. CANPOL, the policing arm of CANADEM, currently has some 800 retired Canadian police officers on its roster, most of whom have considerable international experience and relatively few domestic encumbrances. Indeed, retired officers are becoming a fixture of international

\footnotetext{
${ }^{16}$ Comments made by Glenn MacPhail, a retired RCMP officer with substantial international experience, at the workshop "Canada and the Challenge of Post-Conflict Policing," Ottawa, 30 April 2004.
} 
police missions, even if they represent at best a partial solution to the deficiencies of current Canadian and international systems. On the one hand, the UN still prefers to recruit actively-serving officers, partly because of age and fitness issues, ${ }^{17}$ but also because active officers tend to come seconded with sponsoring-government salaries, and are thus less expensive. On the other hand, Canadian policy-makers themselves remain wary of an over-reliance on retired personnel, in part because retired officers are not as accountable to their home governments and in part because they may not enjoy the same kind of access to information or resources in the field as they would if they were full-time employees of their home governments. ${ }^{18}$ At the same time, the use of retired officers in international missions has raised a host of logistical questions, from issues of liability and insurance to more mundane questions of whether retired RCMP officers working abroad should be allowed to wear RCMP uniforms and badges. While none of these challenges is insurmountable, combined they do suggest that while there is a role for retired police officers in international police support missions, there are limits to how far the privatization of police assistance services can be taken.

A broadened and/or deepened Canadian Police Arrangement: If Canada does want to take on a more prominent role in the provision of post-conflict public security, one option would be simply to direct more financial resources into the current CPA. Given that overhead and administration costs are relatively fixed, doubling the CPA operating budget to $\$ 12.6$ million per year should allow Canada to more than double its standing commitment to the United Nations. The fact that different pots of government monies are often drawn on to support larger deployments of Canadian police personnel also means that this is not necessarily a question of finding new money, but rather of pooling existing funds.

At the same time, or alternately, the current CPA could be transformed into a broader vehicle for the delivery of Canadian expertise in the area of security sector reform. Much like the UK's Global Conflict Prevention Pool, such a transformation of the CPA would not only provide a framework for the international deployment of Canadian personnel in the justice and penal sectors, but would also allow the gradual development of a coherent Canadian approach to questions of security sector reform. Moving in this direction would also require a greater commitment to inter-departmental policy coordination, since the CPA's policy-level steering committee is currently required to meet no more than once a year.

The principal drawback of this option lies in the fact that, at least in the policing field, more money will not necessarily fix the current flaws in the CPA. In the absence of a sustained, long-term funding commitment by its government partners, the RCMP still will not be in a position to hire additional police officers to offset the greater numbers of its staff deployed internationally. In this sense, more money might simply add to the current headaches of the RCMP (and of other participating police forces) in terms of having to identify, release, and cover for even greater numbers of field officers. At

\footnotetext{
${ }^{17}$ Author interview with Ajay Bhatnagar, UN Civilian Policing Division, New York, 6 January 2004.

${ }^{18}$ Author discussions with DFAIT officials, Ottawa, 15 January 2004.
} 
the same time, while an expanded CPA might put greater numbers of Canadians into the field, it will not address existing tensions between adequate training and rapid deployment. Finally, as with the previous two options, neither a broadened nor a deepened CPA will facilitate a more robust Canadian contribution to improving current deficiencies within the international system around post-conflict police assistance.

A dedicated International Civilian Police Division: The most ambitious option for upgrading Canadian capacities in the field of international police assistance - and the most logical if Canada is to establish itself as a serious player in this area - is to establish a dedicated international police support division within the RCMP. While requiring a considerable and sustained financial commitment on the part of the Government of Canada - in the neighborhood of \$30-50 million annually ${ }^{19}$ - the creation of a standing unit would give Canada significant capacity not only to provide officers for international missions but also to engage seriously in international training and research. Assuming that half of the standing Canadian unit would be deployed abroad at any one time, this would still leave a substantial number of personnel available to either receive, develop or deliver specialized training in international police assistance, or to form the core of an Canadian policy unit on strengthening international capacities in the area of post-conflict policing.

The idea for a dedicated Canadian international civilian policing unit is not new, and the RCMP has been advocating such a move for a number of years. ${ }^{20}$ From an RCMP perspective, the creation of an international standby unit neatly overcomes the tensions between international and domestic policing responsibilities, as the unit would be fully separated from the RCMP's domestic policing arms, and stable funding would enable additional hiring to fill gaps left by police officers drawn into the unit. At the same time, the formation of the unit would entail the automatic pre-selection of officers for overseas deployments, enabling these officers to receive substantial pre-deployment training.

The creation of an international civilian policing unit would also require alterations to current administrative arrangements. Given the level of funding involved, funding for this new initiative should come directly from the Treasury Board, rather than through CIDA. ${ }^{21}$ This would not only simplify administrative arrangements, but shift CIDA - which has proven to be somewhat ambivalent in its approach to the CPA - from the role of funder to the role of advisor. An inter-departmental committee could still be struck to manage overall policy direction for the new mechanism, and this committee could form the nucleus for an integrated Canadian strategy on security sector reform issues.

Establishing a standing Canadian capacity for international police assistance would be a bold step, and would send a strong signal that Canada is willing to put its money where its mouth is on

\footnotetext{
${ }^{19}$ This estimate is based on the current CPA ratio of $\$ 150,000$ per officer deployed per year. An annual budget of $\$ 30$ million would provide for a 200-person standing force.

${ }^{20}$ See also Paul LaRose-Edwards, “Canadian CivPol Division,” (Ottawa: CANADEM, May 1999).

${ }^{21}$ Coates, "Canadian Police as Peacekeepers," 46.
} 
questions of international peace and security. As well, since police assistance is increasingly considered part of official development assistance, it could also help bring Canada's official aid levels back to respectable levels. Realistically, however, getting this issue on the government's foreign policy agenda will require a considerable lobbying effort from a range of directions, particularly given the relatively low profile of post-conflict policing both within the Canadian public and within the Canadian government.

\section{Conclusion}

In this paper I have made the case that questions of post-conflict public security are increasingly recognized as essential to the success or failure of peacebuilding operations, and have argued that Canada should seriously consider upgrading its capacities in this area as part of a renewed Canadian commitment to engaged multilateralism. Enhancing Canadian capacities for the provision of post-conflict police assistance would not only be consistent with explicit Canadian foreign policy aims, it would also add some needed balance between commitments and capabilities. At the same time, Canada currently enjoys a strong international reputation in the area of policing, and an equally strong - if slowly waning reputation in the field of international peacekeeping. An expansion of Canadian capacities for postconflict police assistance would build on both these traditions, and re-assert Canada's stance as a champion of constructive solutions to international conflict. On the financial side, while establishing a permanent Canadian standby unit for international post-conflict policing would entail considerable expansion of the monetary envelope currently devoted to such efforts, the required investment is not out of line given Canada's $\$ 3.1$ billion aid budget, and given the widely-acknowledged links between insecurity and underdevelopment. If, as noted above, there can be no development without security, then practically speaking an investment in public security is an investment in development.

More broadly, there is little question that expanding Canadian capacities for post-conflict policing would help fill existing gaps within international capacities in this area. Recent events in Haiti suggest that the provision of post-conflict public security will continue to stress the resources of the international community for many years to come. Conversely, ongoing instability in both Iraq and Afghanistan suggest that failing to respond to this challenge risks condemning post-conflict societies to future cycles of strife, conflict, and misery. By taking up its end of this challenge, Canada can not only position itself as an international leader in this area and enhance its international reputation, it can also make a concrete and long-lasting contribution to international stability. 